\title{
STUDY ON THE STUDENTS' APTITUDE AND OPENNESS FOR THE USE OF VIRTUAL REALITY AND AUGMENTED REALITY TECHNOLOGIES IN EDUCATION AND INSTRUCTION
}

\author{
Ioan VIRCA, Vasile CĂRUȚAȘU, Maria-Lucia RUSU, Claudiu VESA \\ "Nicolae Bălcescu" Land Forces Academy, Sibiu, Romania \\ virca.ioan@armyacademy.ro, carutasu.vasile@armyacademy.ro, \\ rusu.maria@armyacademy.ro, vesa.claudiu@armyacademy.ro
}

\begin{abstract}
This paper is designed to quantitatively measure the level of aptitude and availability of the students from the "Nicolae Bălcescu" Land Forces Academy in Sibiu for the use of virtual reality (VR) and augmented reality (AR) technologies as teaching tools in the process of education and instruction. The paper is a first stage of a broader research topic, the results of which will be addressed to both teachers and researchers, as well as students and other categories of trainees. The introductory part of the paper analyses the importance of $V R$ and AR technologies as learning environments for the military education system in particular and the advantages of using them for the cadets' combat training. Also, the main characteristics of the three types of reality, environmental, virtual and augmented, are highlighted, which allow a better understanding of the structure and operation of AR and VR. The research methodology was then developed, establishing a survey by applying a questionnaire on a sample of 300 students from the academy and then processing and interpreting the results obtained. The conclusions of the paper show the general predisposition of students to understand and use the two technologies both as tools of learning in didactic teaching and as instruments of improving the skills of fighters in modelling and simulating military actions.
\end{abstract}

Keywords: education, instruction, augmented reality, virtual reality, cadets

\section{Introduction}

Virtual reality (VR) and augmented reality (AR) have become present in many areas of human activity, being able to solve problems or find solutions that in the surrounding reality are at the stage of ideas, concepts or projects. Virtual reality models the surrounding reality at the desired characteristics and simulates the behaviour of models, allowing for remote operation of the results obtained [1]. Instead, augmented reality complements the surrounding reality with virtual elements (video information, text, images, icons, etc.) [2], which are arranged as "layers" with the help of the computer, being able to provide such information and instructions, maps, locations, and so on. Moreover, by means of $5 \mathrm{G}$ technology, VR and $\mathrm{AR}$ acquire new dimensions regarding the possibilities to transmit information at a distance, i.e., to be able to carry out distance or online learning. All the areas of activity mentioned above can be improved due to the ability to interact in real time and the massive information flows that can be transmitted with 5 G networks [3].

For the military system, specific information can be passed on to fighters in the form of combat mission orders or can be a means of instruction. In the education system in general, including the military one in which an important component is that of specific 
instruction, VR and AR are becoming more and more teaching and learning technologies for teachers and students or trainees, due to the advantages of these technologies and the performance of the currently-used devices (laptops, tablets, smartphones), as well as the skills and openness of students to operate with the respective devices and related software. In this context, within the military higher education system in Romania, education is currently undergoing an extensive transformation process in which educational disciplines or groups of disciplines adapt to the coordinates of modelling-simulation with the help of VR and AR learning environments. Consequently, these learning environments become complex, in which "their characteristics do not act in isolation, but are in interaction, playing an important role in shaping the learning process and the learning outcomes" [4].

These new learning environments require a multiple combination of knowledge and skills that constitute a "new area of multidisciplinary research" [5]. In this study, VR can be created with VBS-3 [6] and VBS-4 [7] applications and will become a teaching methodology that will give students access to immersive experiences that will capture their attention and stimulate their imagination, all leading to increased creativity, becoming themselves creators of virtual reality by translating real exercises and scenarios into VR applications. The themes and projects of the students will determine an exponential multiplication of the content of the educational disciplines and will open new directions of study and research.

The advantages of using VR and AR to train students in the military are the following $[8,9,10]$ :

- improving the communication between fighters and the fighting spirit during combat actions by immersive involvement in the specific role within the structure of which the military is part (team, group, platoon);

- for modelling any mission and simulating the projected tactical scenario, VBS-3 and VBS-4 applications allow the selection from databases of a wide range of individual military equipment, combat vehicles, weapons systems, etc. [6,7], both for the own forces and for the enemy forces, which will determine a complex character to the whole instructive approach;

- different tactical situations can be simulated with a large number of military units and the performance of weapons systems and other equipment can be evaluated [8];

- VBS-4 allows for the simulation to be performed in geographical locations where missions can be really performed, benefiting from the existence in the database of all geographical areas on a global scale;

- the instruction with VR and AR can be done at a low cost, without involving the additional allocation of material, human and financial resources, the instruction time being also greatly reduced [9];

- the instruction, respectively learning based on virtual reality, increases the level of attention of students by $100 \%$ and improves the test results by $30 \%$ [10].

In working with the two learning environments, it is important to understand their specific characteristics in relation to the characteristics of the surrounding reality, in order to better perceive the need for psychomotor involvement that the students must manifest. The students must also know the level of skill they must have for operating with the two environments, thus the personal openness as a whole. Table no. 1 presents the main characteristics of the above-mentioned environments. 
Table 1 Features of the surrounding, virtual and augmented reality

\begin{tabular}{|c|c|c|c|}
\hline Characteristic & Surrounding reality & $\begin{array}{l}\text { Virtual } \\
\text { reality }\end{array}$ & $\begin{array}{l}\text { Augmented } \\
\text { reality }\end{array}$ \\
\hline $\begin{array}{l}\text { Form of the } \\
\text { learning } \\
\text { environment }\end{array}$ & Natural & $\begin{array}{l}\text { Completely } \\
\text { simulated }\end{array}$ & $\begin{array}{c}\text { Virtual layer over the } \\
\text { filmed surrounding } \\
\text { reality }\end{array}$ \\
\hline Availability & Tactile & $\begin{array}{l}\text { HMD (head mounted } \\
\text { display-headset), } \\
\text { smartphone, VR and } \\
\text { PC product or consoles }\end{array}$ & $\begin{array}{c}\text { Headset, tablet, } \\
\text { smartphone camera }\end{array}$ \\
\hline $\begin{array}{l}\text { Visualisation of } \\
\text { life-size images }\end{array}$ & $\begin{array}{l}\text { Normal or reduced, } \\
\text { influenced by the } \\
\text { weather conditions }\end{array}$ & $\begin{array}{l}\text { Very successful } \\
\text { reproducibility of the } \\
\text { surrounding reality }\end{array}$ & $\begin{array}{l}\text { Integration of the } \\
\text { surrounding reality } \\
\text { with sensory inputs }\end{array}$ \\
\hline $\begin{array}{l}\text { Correlation } \\
\text { between body } \\
\text { organs involved } \\
\text { in operating with } \\
\text { the environment }\end{array}$ & Normal correlation & $\begin{array}{l}\text { Normal correlation or } \\
\text { possible slower } \\
\text { movements }\end{array}$ & $\begin{array}{l}\text { Normal correlation or } \\
\text { possible slower } \\
\text { movements }\end{array}$ \\
\hline $\begin{array}{l}\text { Response time to } \\
\text { exploring the } \\
\text { environment }\end{array}$ & Limited & Extremely low & Extremely low \\
\hline $\begin{array}{l}\text { The degree of } \\
\text { immersion of the } \\
\text { operator in the } \\
\text { working } \\
\text { environment }\end{array}$ & Limited & $\begin{array}{c}\text { Total } \\
\text { (physically and } \\
\text { mentally) }\end{array}$ & $\begin{array}{c}\text { Total } \\
\text { (physically and } \\
\text { mentally) }\end{array}$ \\
\hline
\end{tabular}

\section{Research methodology}

Given that modern equipment using VR and AR technologies has been purchased in the institution, this approach is natural.

The authors of the paper know the potential of using these tools that support the instructive-educational process and have the certainty that the other teachers, researchers and instructors in the institution will implement them in the transmission of knowledge.

Based on the knowledge presented in the introductory part, the authors established as appropriate the need to apply a questionnaire or survey in order to assess the quantitative level of openness and aptitudes of the students of "Nicolae Bălcescu" Land Forces Academy of Sibiu regarding the use of virtual reality and augmented reality as teaching methods in education and specific military activities, instruction respectively, from the perspective of the increasing use of these technologies in the distance or hybrid teaching system [11]. 
In this sense, the transformation or adaptation of certain educational disciplines (courses, seminars, laboratories) to the specifics of these technologies also becomes mandatory due to the fact that the IT infrastructure and JCATS and VBS-3/ VBS-4 applications existing in the academy facilitate this process.

Regarding the potential of students, by applying the questionnaire mentioned above, the authors want to investigate the openness of the students in the institution to these modern teaching aids.

The authors started from the assumption that the students are familiarized with utilizing the VR and AR technologies in improving the instructive-educational process and are open and have aptitudes for learning by their means. They have formulated the following hypotheses:

a) at least half of the subjects have used VR and AR technologies so far;

b) the main advantages of using the technologies are the enhancement of the process of knowledge consolidation and capturing the attention;

c) all the cadets show openness for using the VR and AR technologies.

To validate these assumptions, the questionnaire was applied in the 13-15 May 2021 period, on a sample of 300 students from the I and II of years of study, of which 108 girls and 192 boys. The students represented all the programs of study for the relevance of the aptitude level, considering the different specifics of the students' specialization, between disciplines with a more pronounced technical character and socio-behavioural disciplines.

The distribution of students by years of study, programs of study and the two categories of sexes is presented in table no. 2 .

\section{Results obtained}

The designed questionnaire includes 9 questions, the results obtained from the answers provided by students being presented below. We mention that the last question referred to the gender categories of students, for the relevance of the girl-boy relationship, as a requirement of a sociological survey [12].

The students' answers are further presented, being grouped on categories of sex and year of study.

Table 2 Students' distribution

Question no. 1: Are you aware of this tendency of using new didactic methods with the help of VR and AR technologies?

\begin{tabular}{|l|c|c|}
\hline \multicolumn{1}{|c|}{$\begin{array}{c}\text { Study program/ } \\
\text { year of study }\end{array}$} & Girls & Boys \\
\hline $\begin{array}{l}\text { Economic and Financial } \\
\text { Management/ Public } \\
\text { Administration/I }\end{array}$ & 15 & 12 \\
\hline $\begin{array}{l}\text { Engineering and } \\
\text { Management in the Field } \\
\text { of Military } \\
\text { Communications/I }\end{array}$ & 24 & 30 \\
\hline Military Leadership /I & 12 & 18 \\
\hline $\begin{array}{l}\text { Management of } \\
\text { organization/I }\end{array}$ & 24 & 72 \\
\hline $\begin{array}{l}\text { Economic and Financial } \\
\text { Management /II }\end{array}$ & 6 & 4 \\
\hline Military Leadership /II & 15 & 49 \\
\hline $\begin{array}{l}\text { Accounting and } \\
\text { Management } \\
\text { Information System/II }\end{array}$ & 12 & 7 \\
\hline Total & 108 & 192 \\
\hline Overall total & $\mathbf{3 0 0}$ \\
\hline
\end{tabular}

\begin{tabular}{|l|c|c|}
\hline Girls/Boys/Year & YES & NO \\
\hline Girls/Year I & 35 & 40 \\
\hline Girls/Year II & 19 & 14 \\
\hline Boys/Year I & 80 & 52 \\
\hline Boys/Year II & 52 & 8 \\
\hline Total General & \multicolumn{2}{|c|}{300} \\
\hline
\end{tabular}

Question no. 2: Have you ever tested the $\mathrm{VR}$ and AR technologies (games, applications, etc.)?

\begin{tabular}{|l|c|c|}
\hline Girls/Boys/Year & YES & NO \\
\hline Girls/Year I & 31 & 44 \\
\hline Girls/Year II & 15 & 18 \\
\hline Boys/Year I & 100 & 32 \\
\hline Boys/Year II & 40 & 20 \\
\hline Total General & \multicolumn{2}{|c|}{300} \\
\hline
\end{tabular}


Question no. 3: What new thing would you like for the VR and AR technologies to bring about in education?

a) stronger interactivity with the learning environment;

72 girls and 129 boys have chosen this response.

b) easier and quicker comprehension of knowledge;

94 girls and 148 boys have chosen this response.

c) development of creativity;

71 girls and 112 boys have chosen this response.

Question no. 4: Which of the following advantages do you consider to have the major benefit of using VR and AR technologies in the training process of cadets in the Land Forces Academy?

a) arouses the students' curiosity;

40 girls and 67 boys have replied like this.

b) encourages the students' curiosity;

29 girls and 48 boys have replied like this.

c) perfects the military training;

39 girls and 77 boys have replied like this.

Question no.5: Do you think that learning with the VR and AR technologies will capture and retain the tudents' attention during class or instruction?

\begin{tabular}{|l|c|c|}
\hline Girls/Boys/Year & YES & NO \\
\hline Girls/Year I & 75 & 0 \\
\hline Girls/Year II & 33 & 0 \\
\hline Boys/Year I & 129 & 3 \\
\hline Boys/Year II & 59 & 1 \\
\hline Total General & \multicolumn{2}{|c|}{300} \\
\hline
\end{tabular}

Question no. 6: To what extent do you consider that you currently have skills for the use of VR and AR technologies in the learning process?

a) to a very small extent;

15 girls and 13 boys have responded like this.

b) to a small extent;
29 girls and 40 boys have responded like this.

c) to an average extent;

34 girls and 69 boys have responded like this.

d) to a great extent;

25 girls and 45 boys have responded like this.

e) to a very great extent;

5 girls and 25 boys have responded like this.

Question no. 7: Consequently, to what extent do you consider that you have the availability to improve your skills regarding the use of VR and AR technologies in the educational process?

a) very little;

3 girls and 2 boys have chosen this response.

b) little;

8 girls and 8 boys have chosen this response.

c) average;

29 girls and 60 boys have chosen this response.

d) much;

44 girls and 66 boys have chosen this response.

e) very much;

24 girls and 56 boys have chosen this response.

Question no. 8: Do you think that the VR and AR technologies will become important influencing factors in the future of youth education in general?

\begin{tabular}{|l|c|c|}
\hline Girls/Boys/Year & YES & NO \\
\hline Girls /Year I & 73 & 2 \\
\hline Girls/Year II & 33 & 0 \\
\hline Boys/Year I & 129 & 3 \\
\hline Boys/Year II & 59 & 1 \\
\hline Total General & \multicolumn{2}{|c|}{300} \\
\hline
\end{tabular}

\section{Discussions}

Based on the answers obtained, the first hypothesis is found to have been verified, 
both in terms of knowledge and use of the two technologies by students. We notice that this is mainly due to the boys, who are more inclined, by their natural nature, to use these technologies.

Regarding the second hypothesis, it is observed that it is not verified, even if we would have expected these technologies to help students to more easily understand the new information taught. They appreciate more the interactivity that the VR and AR technologies imply in the instructiveeducational process.

The third hypothesis is verified, over $95 \%$ of he respondents show openness and a positive perception of these new technologies.

The formulated hypotheses are part of a broader research that addresses other issues related to the VR and AR technologies in terms of studying the correlations between the various elements included in the questionnaire, in the field of military education and in the context of an online education process.

According to the research results, the availability and skills developed towards VR and AR experiences are presented by male students, who have a greater inclination than female students towards the technical side and towards digitalization.

\section{Conclusions}

The predisposition to know and use VR and AR depends largely on native skills but also on individual perception of these new realities. The new generation is endowed with skills developed in the field of IT and digitalization. Their adaptation to the novelties of the virtual environment is relatively easy and comes naturally, without sustained efforts.

The control elements, such as openness and enthusiasm, developed for the use of these realities are stimulated by the perception of the beneficiaries. The contemporary generation of students have the advantage of benefiting from immersive technologies and innovations with artificial intelligence. Using these realities offers a completely different experience than the traditional one, much more amplified, in which the military student is better prepared to become a future leader.

With the help of these smart technologies, courses, seminars and laboratories, information can be incorporated in a more efficient, faster and more interactive way. Learning with AR offers a more complex understanding of information, multidisciplinary development, sustainable learning, physical performance and student motivation. The rapid openness and low costs are advantages that will obviously increase the spread of VR and AR in the educational future.

Strengthening the use of the VR and AR technologies in education and instruction depends on the aptitude and perception of students, led mainly by the teacher and instructor.

The decisive factor is the teacher, who has a considerable impact on the students' perceptions by:

- designing and adapting the contents to the new reality;

- empathy and ability to interact;

- critical and creative thinking;

- flexibility in the use of VR and AR.

The student's openness supposes three aspects:

- preference for the new learning methods;

- confidence in using the immersive technology;

- capacity to use the new reality.

The perspectives of perception are influenced by the agreeableness, conscientiousness and personality of the beneficiaries. The extroverted and sociable students have positively perceived the learning with the help of VR and AR, because they are oriented towards creativity, interaction, innovation, expressiveness and visibly connected with the outer space. Their predisposition to teamwork harmoniously blends with the AR effect, which develops participatory thinking, 
responsibility and solidifies collaborative education.

The introverted students showed a more reserved degree of enthusiasm at their first interaction with VR and $\mathrm{AR}$, but as they became aware of the beneficial effects of this new reality, they found that it gave them the opportunity to practice complex, critical, anticipatory thinking, problem solving. from different perspectives and the development of the capacity for analysis and projection.

AR tools allow students to benefit from the role of demiurge of virtual reality, where simulation helps in the aptitude and cognitive development. This is important in promoting: creativity, empathy, analysis, coding/decoding and the ability to find solutions.

If in the beginning the immersive technology was seen as "entertainment", now it plays a role in enhancing knowledge and creativity [13]. The students' attention must be channeled and focused by stimulating imagination in learning. VR and AR amplify the world of knowledge through multidisciplinary, aptitude and cognitive development.

This paper is part of the research project "Study on achieving modalities of using augmented reality in the military education field in the context of conducting an online education process" within the Sectoral Research-Development Plan of the Ministry of National Defense.

\section{References List}

[1] Cedric Westphal. Challenges in Networking to Support Augmented Reality and Virtual Reality. IEEE ICNC Journal, 2017.

https://d1wqtxts1xzle7.cloudfront.net/57978261/westphal2017challenges.

[2] Pochtoviuk Svitlana I., Vakaliuk Tetiana A., Pikilniak Andrey V. Possibilities of application of augmented reality in different branches of education. AREdu 2019, Proceedings of the 2nd international Workshop on Augmented Reality in Education, Kryvyi, Ukraine, March 22, 2019, Pp. 92-106. http://ceur-ws.org/Vol-2547/

[3] Xiaohu Ge, Linghui Pan, Qiang Li, Guoqiang Mao, Song Tu. Multipath Cooperative Communcations Network for Augmented and Virtual Reality Transmission. IEEE Transaction on Multimedia, Vol. 19, No. 10, October 2017, pp. 2345-2358.

https://ieeexplore.ieee.org/stamp/stamp.jsp?tp=\&arnumber $=7997740$

[4] Salzman M.C., Dede C., Loftin R.B., Chen J. A Model for Understanding How Virtual Reality Aids Complex Conceptual Learning. Massachusetts Institute of Technology: Presence Journal, ,Vol. 8, No. 3, June 1999, [updated date; cited date], pp. 293-316. http://file://C:/Users/yoga1/Documents/KBO-2021/VR-1\%20articol.pdf

[5] Ajey Lele. Virtual reality and its military utility. Journal of Ambient Intelligence and Humanized Computing, 4. 28 May 2011, pp. 17-26.

http:// Virtual reality and its military utility | SpringerLink

[6] https://bisimulations.com/products/vbs3

[7] https://bisimulations.com/products/vbs4

[8] Xinxiong Liu, Jing Zhang, Guoxiang Hou, Zenan Wang. Virtual Reality and Its Application in Military. 2nd International Symposium on Resource Exploration and Environmental Science. IOP Conf. Series: Earth and Environmental Science 170 (2018) 032155. Doi :10.1088/1755-1315/170/3/032155

Liu_2018_IOP_Conf._Ser._Earth_Environ._Sci._170_032155 (1).pdf 
[9] Pandelidis Veronica S. Reasons to Use Virtual Reality in Education and Training Courses and a Model to Determine When to Use Virtual Reality. Themes in Science and Technology Education. Special Issue, Pages 59-70. Klidarithmos Computer Books.

22-77-1-PB.pdf

[10] Noureddine Elmqaddem. Augmented Reality and Virtual Reality in Education. Myth or Reality? International Journal of Emerging Technologies in Learning iJET. Vol. 14, No. 3, 2019, pp. 234-242.

https://core.ac.uk/download/pdf/234939951.pdf

[11] Chelcea, S. Metodologia cercetării sociologice: metode cantitative și calitative, third edition, Economic Publishing House, Bucharest, 2007.

[12] Coman, C. Despre eşantionare, West Publishing House, Timişoara, 2018.

[13] Badea D., Bârsan G., Bucovețchi O., Mănescu G., Macovei C., Iancu D., Approaching young generation education for security between managerial paradigms specific to standardized need and assumed freedom, Proceedings of the $13^{\text {th }}$ International Management Conference, "Management Strategies for High Performance", $31^{\text {st }}$ October- $1^{\text {st }}$ November, 2019, București, România, pp. 326-336, ISSN 2286-1440. 